UCRL-ID-119535-1

\title{
Progress Reports for Period November 1-30, 1994 Joint UK/US Radar Program
}

\author{
R. E. Twogood \\ J. M. Brase \\ D. D. Mantrom \\ D. H. Chambers \\ H. F. Robey
}

December 19, 1994
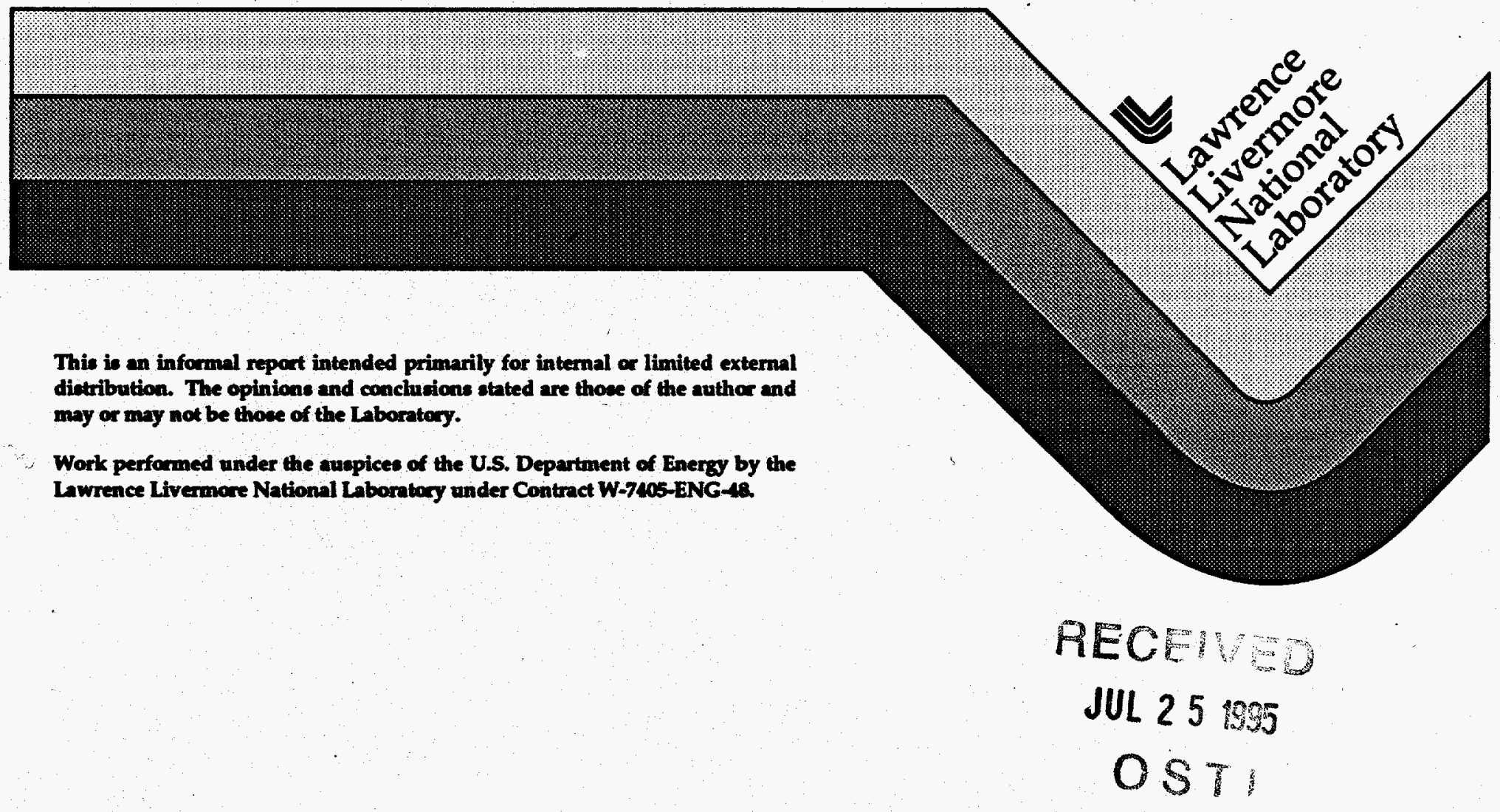


\section{DISCLAIMER}

This document was prepared as an account of work sponsored by an agency of the United States Government. Neither the United States Government nor the University of California nor any of their employees, makes any warranty, express or implied, or assumes any legal liability or responsibility for the accuracy, completeness, or usefulness of any information, apparatus, product, or process disclosed, or represents that its use would not infringe privately owned rights. Reference herein to any specific commercial product, process, or service by trade name, trademark, manufacturer, or otherwise, does not necessarily constitute or imply its endorsement, recommendation, or favoring by the United States Government or the University of California. The views and opinions of authors expressed herein do not necessarily state or reflect those of the United States Government or the University of California, and shall not be used for advertising or product endorsement purposes.

This report has been reproduced directly from the best available copy.

Available to DOE and DOE contractors from the Office of Scientific and Technical Information P.O. Box 62, Oak Ridge, TN 37831

Prices available from (615) 576-8401, FTS 626-8401

Available to the public from the

National Technical Information Service

U.S. Department of Commerce 5285 Port Royal Rd.

Springfield, VA 22161 


\section{DISCLAIMER}

Portions of this document may be illegible in electronic image products. Images are produced from the best available original document. 
Progress Reports for period November 1-30, 1994

Joint UK/US Radar Program 12/19/94

Organization: LLNL

Program: P.LLN.1010 Airborne RAR/SAR
Principal Investigator: Richard E. Twogood

Current Objectives:

Modify Hughes $x$-band radar for airborne implementation.

Upgrade to polarimetry, high-power, and add SLAR mode.

Deploy in UK/US field experiments as needed.

\section{Recent accomplishments:}

Work continued on hardware procurements, system integration, and software development for the LLNL-led tasks. Hughes Aircraft re-started work on the radar design and associated control hardware/software (work had stopped in October due to lack of funding).

The overall radar and testbed is now scheduled for engineering checkout in April 1995, pending the arrival of FY95 funds as expected (12/94).

Milestones for the reporting period:

Ongoing design work re-started after stoppage of work in October; no major milestones scheduled for November.

Expected milestones for the ensuing period:

April 1995 Engineering Checkout(s)

June 1995 First experimental deployment

\section{Other Issues:}

There has been a few week slip due to the absence of funds on 10/1/94;

Hughes has moved some of the radar work back until the next increment of funding is available (FY94 funds sent out by ISSO on 10/25).

\section{Planned expenditures versus actuals:}

FY95 Budget Plan: \$1500K

November 94 costs: $\quad \$ 43 \mathrm{~K}$

Year-to-date costs: $\quad \$ 107 \mathrm{~K}$ 
Organization: LLNL

Program: P.LLN.1020 Radar Data Processor

Principal Investigator: Richard E. Twogood

\section{Current Objectives:}

Integration and test of the real-time SAR processor for the Hughes airborne radar; define and develop the SAR Doppler and related analysis software for this unique system; develop the similar system for the UK testbed (OITB)

\section{Recent accomplishments:}

The radar data processor computer hardware has all been successfully integrated. The baseline SAR processor was completed ahead of schedule, successfully running on a single node. Test programs were also successfully run on the Mercury parallel processor; mods to the SAR processor for multiple-node execution are underway (necessary for real-time operation with Hughes radar).

Milestones for the reporting period:

Baseline SAR processor for Hughes system running on single node.

Expected milestones for the ensuing period:

Preliminary design review with the UK (Keith Ward) during December 1994. Baseline SAR processor software to be completed by early December.

\section{Other Issues:}

None.

Planned expenditures versus actuals:

FY95 Budget Plan: $\quad$ \$750K

November 94 costs: $\quad \$ 92 \mathrm{~K}$

Year-to-date costs: $\quad \$ 202 \mathrm{~K}$ 
Organization: LLNL

Program: P.LLN.1030 Ground-based SAR Signal Processing Workstation

Principal Investigator: James M. Brase

Current Objectives:

Develop capabilities for motion compensation and autofocus for Hughes SAR and UK system. Enhance SAR processors with multi-look software. Analyze the low-grazing angle (LGA) processing steps and improve performance of LGA processing.

\section{Recent accomplishments:}

LGA Doppler processing software was successfully completed and checked out. Work continued on implementing the software changes suggested by Roger Manasse to speed up processing of LGA data and detection techniques.

Milestones for the reporting period:

No planned milestones in November.

Expected milestones for the ensuing period:

Manasse modifications to be implemented by December 1994.

Full motion compensation software for Hughes airborne system by March 95 . Autofocus upgrade to processor by April 1995.

\section{Other Issues:}

None.

Planned expenditures versus actuals:

FY95 Budget Plan:

November 94 costs:

$\$ 750 \mathrm{~K}$

Year-to-date costs:

$\$ 15.9 \mathrm{~K}$

$\$ 56 \mathrm{~K}$ 
Organization: LLNL

Program: P.LLN.1040 Static Airborne Radar

Principal Investigator: Richard E. Twogood

Current Objectives:

Procure GFE excess equipment including aerostats, platforms, and ancillary systems. Perform checkout of hardware. Assess options for stabilized realaperture radar experiments using these aerostats systems. FY95 funding permitting, include these systems in radar experiments beginning in summer 1995.

\section{Recent accomplishments:}

Further checkout of the aerostats, mooring platforms, and support systems was performed. Cost estimates were developed for the support of the COPE trial, with the APS 143 radar on the aerostat. The LLNL-owned system obtained separately from Beaumont, Texas was studied for potential mobile platform support and has emerged as the best option for the planned west coast activities. Further discussions with Autec regarding the east coast system were held and no major issues have arisen.

Milestones for the reporting period:

Initial hardware assessments completed; plans and cost estimates for initial aerostat deployment performed.

Expected milestones for the ensuing period:

Down-select from options once FY95 funding received (December 1994).

Determine issues and costs for IR support at October 95 Autec test.

Initial radar system checkout and experiments, June 1995.

\section{Other Issues:}

The UK has indicated providing an aerostat for Autec in October is a high priority. IR systems would be deployed (presumably the existing ERIM sensors already successfully used, but they would need to be fitted to the aerostat). The existing budget for this task will be insufficient for both objectives (radar support for COPE and IR support for Autec). At this point it appears slippage of the radar support is most likely unless additional funds for $\mathbb{R}$ support are available through the $\mathbb{R}$ tasks.

Planned expenditures versus actuals:

FY95 Budget Plan: $\quad \$ 1000 \mathrm{~K}$

November 94 costs: $\quad \$ 36.7 \mathrm{~K}$

Year-to-date costs: . $\quad \$ 117 \mathrm{~K}$ 
Organization: LLNL

Program: P.LLN.1050 Multi-Aperture Space-Time Array Radar

Principal Investigator: James M. Brase

Current Objectives:

Perform feasibility study and preliminary design of a multi-aperture radar for high resolution, in both range and azimuth, imaging of the ocean surface.

Recent accomplishments:

None - project starts upon receiving FY95 funds.

Milestones for the reporting period:

None - project not yet started.

Expected milestones for the ensuing period:

Initiation of project circa December 1994; preliminary discussion of system options with Keith Ward by December.

Other Issues:

None.

Planned expenditures versus actuals:

FY95 Budget Plan: \$200K

November 94 costs: $\quad \$ 0 \mathrm{~K}$

Year-to-date costs: $\quad \$ 0 \mathrm{~K}$ 
Organization: LLNL

Program: P.LLN.1060 Radar Field Experiments

Principal Investigator: David Mantrom

Current Objectives:

Complete analysis of Loch Linnhe 1994 data. Plan and prepare for 1995 trials, including static airborne system test(s), and a potential detection test in summer or early autumn 1995.

Recent accomplishments:

Analyzed density stratification/shear profile data from Loch Linnhe 94. A report on the profile measurements and corresponding dispersion relations and eigenfunctions has been completed and distributed to program

participants. A presentation on the effect of shear on Loch Linnhe ship wakes was presented at the LLNL meeting.

Preliminary planning for FY95 field experiments has begun, and all potential field experiment activities discussed in a meeting at LLNL on 12/1/94 (Kulla, Ward, Barber, Holliday, Twogood, Mantrom, and others were present). Issues and trade-offs for all of the following were discussed: potential use of Sogneford as a site for UK test (Ward to check into further, but 95 test appears very unlikely); Autec test in June/July (favorable radar conditions; logistics issues of UK involvement need consideration; Kulla asked Ward and Barber to consider impact of future use of US targets; recommendation on how to proceed will be made in December); Autec test in October (UK asked for aerostat support for IR work; radar unfavorable in October); COPE (possible support by Hughes airborne radar, aerostat radar, and CMA but cost issues may prevent). Sand banks and Tregantle collections were also discussed. A summary of the above is being prepared prior to final 95 priorities and budget cut-offs.

Milestones for the reporting period:

Preliminary reports on LL94 experiment written.

Expected milestones for the ensuing period:

Determination of 1995 experiment plans with UK researchers, December 94. Initial field experiment reports and community-wide meetings by Feb. 1995.

Other Issues:

None.

Planned expenditures versus actuals:

FY95 Budget Plan: $\quad \$ 2000 \mathrm{~K}$

November 94 costs: $\quad \$ 186.1 \mathrm{~K}$ (mostly accruals from previous expts)

Year-to-date costs: $\quad \$ 305.6 \mathrm{~K}$ 
Organization: LLNL

Program: P.LLN.1070 Data Analysis and Detection Theory

Principal Investigator: James M. Brase

Current Objectives:

Complete baseline analysis of Loch Linnhe data.

Complete report on MTF for LGA data (1989-94 data sets).

Continue Doppler analysis and detection implications.

Analysis of UCSB data as it comes in.

Recent accomplishments:

Detailed Doppler analysis of the priority runs from loch Linnhe continued.

Quick-look data reports in preparation..

A two-day workshop was held at LLNL to address status of publication of ship wake findings from the UK/US program (11/29-30/94). In addition to the researchers actually working on the ship wake issues, many organizations sent 'observers' to the meeting and there were many broader-ranging technical issues informally discussed. Plans for future publication of results were mapped out; further coordination among the principals was agreed to.

Milestones for the reporting period:

Two-day ship wake meeting held.

Expected milestones for the ensuing period:

Baseline analysis reports for Loch Linnhe 94 completed and distributed, 12/94.

Other Issues:

None.

Planned expenditures versus actuals:

FY95 Budget Plan: $\quad \$ 700 \mathrm{~K}$

November 94 costs: $\quad \$ 159.2 \mathrm{~K}$

Year-to-date costs: $\quad$ \$314K 
Organization: LLNL

Program: P.LLN.1080 Management

Principal Investigator: Richard E. Twogood

\section{Current Objectives:}

Provide ongoing management oversight and support for the Joint UK/US Radar Program (Twogood) and staff support in Washington for the ASAP program office (Thomson, Hutchins, Chocol), in addition to other consultant and management services (Wells, Manasse, etc.). All administrative support for UK/US program included.

Recent accomplishments:

Coordination of future meetings and new initiatives was performed. Ship Wake meeting at LLNL (11/29-30) and Scientific Coordination Working Group (12/1) were hosted by LLNL. Continued full-time support of ISSO Ballston office by Thomson, Hutchins, and Chocol. Manasse continued providing technical advice for LGA work.

Milestones for the reporting period:

Ship Wake (publication plannning meeting) held at LLNL with excellent progress in plans to document program results.

First Scientific Coordination Working Group meeting held at LLNL.

Expected milestones for the ensuing period:

Ongoing support to ISSO office by program office staff.

Planning meeting at UCSB to be held 12/13-14/94.

\section{Other Issues:}

None.

Planned expenditures versus actuals:

FY95 Budget Plan: $\quad \$ 1000 \mathrm{~K}$

November 94 costs: $\quad \$ 286 \mathrm{~K}$

Year-to-date costs: $\quad \$ 515 \mathrm{~K}$ (includes accruals of overruns from FY94) 
Organization: LLNL

Program: P.LLN.1090 E-2C Radar Data Analysis

Principal Investigator: Charles Rino

Inputs to be provided separately to ISSO directly by Vista Research. 
Organization: LLNL

Program: P.LLN.1110 Modeling and Analysis (LLNL)

Principal Investigator: David Chambers

Current Objectives:

Analysis of Loch Linnhe 1994 hydrodynamics data.

Development of turbulent wake model.

Estimate wind-wave relaxation times.

Recent accomplishments:

Continued analysis of Loch Linnhe hydro data. Obtained initial results showing evolution of wave field due to wind. Continued development of turbulent wake model.

Milestones for the reporting period:

No milestones for November 94 .

Expected milestones for the ensuing period:

Documentation of hydro analysis for Loch Linnhe by December 1994.

Complete turbulent wake source model and comparison with IAP wave tank data.

Other Issues:

None.

Planned expenditures versus actuals:

FY95 Budget Plan: \$330K

November 94 costs: $\quad \$ 16.7 \mathrm{~K}$

Year-to-date costs: $\quad \$ 31.6 \mathrm{~K}$ 


\section{Organization: LLNL}

Program: P.LLN.1150 Modeling and Analysis (Vista)

Inputs to be provided to ISSO directly by Vista Research. 
Organization: LLNL

Program: P.LLN.1170 Current Meter Array

Principal Investigator: David Mantrom

Current Objectives:

Loch Linnhe 1994 CMA data analysis and documentation.

Upgrades to power system, structure, and data acquisition for future tests.

Recent accomplishments:

Analysis of the CMA data from Loch Linnhe has continued. We received the GPS position data for the CMA and target ships; we are re-doing analysis of a prioritized number of runs with the measured positions and cpa times.

Milestones for the reporting period:

None.

Expected milestones for the ensuing period:

Distribution of reports including CMA results from Loch Linnhe 94.

Other Issues:

None.

Planned expenditures versus actuals:

FY95 Budget Plan: $\quad \$ 300 \mathrm{~K}$

November 94 costs: $\quad \$ 0 \mathrm{~K}$

Year-to-date costs: $\quad \$ 10 \mathrm{~K}$ 
Organization: LLNL

Program: P.LLN.1410 UCSB Wave Tank

Principal Investigator: Harry Robey

Current Objectives:

Continue hydro measurements program at UCSB.

Install radars in tank: initially UCSB'S C-band and LLNL's existing wideband; later TRW's $x$-band.

Recent accomplishments:

Progress continued on the radar systems to be deployed at the UCSB tank. The UCSB linear FM radar (5-8 Ghz) is operating; initial analysis of the data shows the radar is working as hoped. The LLNL impulse radar (1-3 Ghz) is operational and back at LLNL. It will return to UCSB in February 95 pending scheduling meetings with UCSB. The TRW radar (10 Ghz) is expected to be ready in January 1995.

A planning meeting for coordinating the UCSB and LLNL work at UCSB is scheduled for mid-December.

Milestones for the reporting period:

None.

Expected milestones for the ensuing period:

Installation of UCSB C-band system 12/94.

Installation of LLNL wideband system (on more or less permanent basis) 2/95.

Planning meeting at UCSB mid-December for UCSB/LLNL/RSRE tasks.

Other Issues:

None.

Planned expenditures versus actuals:

FY95 Budget Plan: $\quad \$ 800 \mathrm{~K}$

November 94 costs: $\quad \$ 0 \mathrm{~K}$ Note: invoicing is irregular-zero costs

Year-to-date costs: $\quad \$ 65.3 \mathrm{~K}$ does not imply work stoppage. 
Organization: LLNL

Program: P.LLN.1420 Stratified Flow Facility

Principal Investigator: Harry Robey

Current Objectives:

Re-start internal wave measurements program with emphasis on turbulence generated IW phenomena.

Recent accomplishments:

Design of the extension of the test section is finished and vendor quotes received; preparations for the test section enlargement in early FY95 are underway.

Milestones for the reporting period:

None.

Expected milestones for the ensuing period:

Extension of test section and system checkout by April 1995.

Other Issues:

None.

Planned expenditures versus actuals:

FY95 Budget Plan: $\quad$ \$200K

November 94 costs: $\quad \$ 8 \mathrm{~K}$

Year-to-date costs: $\quad \$ 19 \mathrm{~K}$ 
Organization: LLNL

Program: P.LLN.1430 Institute of Applied Physics, Russia

Principal Investigator: Harry Robey

Current Objectives:

Conduct wave tank studies at IAP in Russia; current emphasis on extension of previous results to turbulence generated wave effects and study of current shear effects.

Recent accomplishments:

Contract preparations for the next phase of the tank work at the Institute for Applied Physics in Nizhny Novgorod, Russia, were completed. A primary thrust of the work will be to extend the studies previously completed under the last phase of work (mainly turbulence generated internal wave studies) and addition of shear flow in the tank. Contract between IAP and LLNL has been approved by DoE and was sent to IAP for signature. Work commences immediately upon signature by IAP.

Milestones for the reporting period:

New contract approved.

Expected milestones for the ensuing period:

Contract sign-off and commencement of work at IAP in December 94.

Other Issues:

None.

Planned expenditures versus actuals:

FY95 Budget Plan: $\quad \$ 350 \mathrm{~K}$

November 94 costs: $\quad \$ 0 \mathrm{~K}$

Year-to-date costs: $\quad$ \$OK 


\section{Organization: LLNL}

Program: P.LLN.1210 IR Sensor Systems

Principal Investigator: Jerry Belyea

Inputs to be provided to ISSO directly by ERIM. 


\section{Budget Status}

Budget breakdown by individual ISSO work assignment are described in the above individual work unit assignments. Overall UK/US Radar Program funding status is as follows:

\begin{tabular}{|c|c|c|}
\hline November 94 costs: & $\$ 1031.5 \mathrm{~K}$ & \\
\hline Year-to-date costs: & $\$ 1869.7 \mathrm{~K}$ & \\
\hline Ledger liens: & $\$ 2173.4 \mathrm{~K}$ & \\
\hline Pre-liens: & $\$ 625.5 \mathrm{~K}$ & \\
\hline Non-ledger liens: & $\$ 400.0 \mathrm{~K}$ & $\begin{array}{l}\text { (estim.) (unaccrued costs on liens and } \\
\text { preliens plus at-risk funding by } \\
\text { contractors) }\end{array}$ \\
\hline Funds remaining & 35 & (overrun as of $12 / 1 / 94$ ) \\
\hline
\end{tabular}

Discussion of funding: November costs were moderately high, partly due to paying of accrued costs from late FY94 when funding was exhausted. Liens increased by $\$ 500 \mathrm{~K}$ as contractors were funded until $11 / 30 / 94$ on average. These numbers do not even include the payment of ERIM's FY94 overrun (should be invoiced 12/94) or new commitments to ERIM to continue work on IR sensor work. ISSO MIPRed $\$ 3.0 \mathrm{M}$ of FY94 funds on 10/25/94. Those funds were used to pay FY94 overruns and at-risk running by contractors, plus commitments for hardware and contracts for October and November. As the above numbers show, receiving the FY95 funds during December is essential. 